\title{
RICHARD II'S YORKIST EDITORS
}

\author{
EMMA SMITH
}

The possibility that Shakespeare's Richard II was the play described as 'the play of the deposing and killing of King Richard II' and performed on the eve of the Earl of Essex's rebellion in February I60I has assured its status as New Historicism's poster boy. ${ }^{\mathrm{I}}$ The association with Essex makes the play into a perfect exemplar of the Elizabethan theatre's doomed gestures towards subversion; if it didn't exist, we would have to invent it (which, of course, perhaps we have). ${ }^{2}$ But even as criticism has emphasized the radical energies of a play in which a lawful king is deposed without any immediate consequence for his enemies, the editorial tradition has sought to neutralize its political challenge. As this article will show, we read Richard II in texts that are much less comfortable with the fact of the transfer of sovereigns dramatized in the play than its earliest printed versions. Furthermore, in always preferring to reprint the I608 text (Q4) over the popular Elizabethan editions, recent editors have tended to sacralize Richard's kingship, and to neutralize those aspects of the early texts that most challenge a mystificatory myth of unitary monarchical authority. In this delicate play of shifting allegiances and changing sides, few editors have easily followed Shakespeare's own examples of York, Northumberland and even roan Barbary, in accommodating themselves to the Lancastrian rule of Bullingbrook as Henry IV. Rather than seeking the play's political charge in putative early modern performances, therefore, this article describes a Ricardian tradition of editing Richard II in the late twentieth century, an uninvestigated editorial con- sensus silently complicit in minimizing the play's political charge.

Richard II was a substantial success in print. Of the dramatic works, only 1 Henry $I V$, with its crowd-puller Falstaff, equals its five quarto editions in the playwright's lifetime. It was printed in I 597 (QI) and twice in I598 (Q2 and Q3), a frequency suggesting that it was the most popular and marketable play of Shakespeare's early career in print. QI also has a long history of bibliographic endorsement. The editors of the nineteenth-century

I am grateful to Helen Barr, Thea Crapper, Margreta de Grazia, Laurie Maguire, Tiffany Stern and Holger Schott Syme for their comments and insight, and to seminar audiences in Bristol, Oxford, Pennsylvania, Sheffield Hallam, the Shakespeare Institute and Jadavpur University Kolkata, for the chance to rehearse some of my ideas.

I Augustine Philips's examination by Lord Justice Popham and Edward Fenner, I 8 February I60I, Calendar of State Papers, Domestic, 1598-1601, pp. 435-6; Stephen Greenblatt, ed., The Power of Forms in the English Renaissance (Oklahoma, I982), pp. 3-4; Jonathan Dollimore, 'Shakespeare, Cultural Materialism and the New Historicism', in Jonathan Dollimore and Alan Sinfield, eds., Political Shakespeare: New Essays in Cultural Materialism (Ithaca, I985), p. 8.

2 For the idea that scholarship has wilfully distorted the documentary evidence about the performance for its own ideological purposes, see Blair Worden, 'Which Play Was Performed at the Globe Theatre on 7 February i601?', in London Review of Books, 25.13 (Io July 2003). Paul J. Hammer's 'Shakespeare's Richard II, the Play of 7 February I60I, and the Essex Rising', Shakespeare Quarterly, 59 (2008) I-35, reassesses the evidence, and agrees with Worden's claim about Shakespearians' overreading of the incident while arguing that the play performed was indeed Shakespeare's Richard II. 


\section{EMMA SMITH}

Cambridge Shakespeare, the dominant scholarly edition of the period, stated unequivocally that 'the first quarto affords the best text'. ${ }^{3}$ Their successor John Dover Wilson, inspired by the scholarship of the New Bibliography, was the first editor to use QI sustainedly as copy-text, and most modern editors have followed suit. ${ }^{4}$ There is general agreement that QI represents a remarkably good text, described variously as probably 'set from well-ordered authorial papers', 5 'the text closest to Shakespeare's holograph', 'authoritative', 7 'a generally satisfactory witness to what may be supposed to have stood in Shakespeare's autograph'. ${ }^{8}$ Yet despite this consensus, no modern edition follows its logic: QI Richard II is never considered a recoverable, integral text in the way that recent revisionist bibliography has unconflated King Lear and Hamlet. Even the recent interest in early editions of Shakespeare's plays has not identified Q I Richard II as an autonomous text, and it is the only one of the quartos which diverges significantly from $\mathrm{F}$ not to be included as a separate text in The New Cambridge Shakespeare: the Early Quartos series.

All modern editions of Richard II, and indeed all editions since I608, import some I60 lines, first printed in Q4 of I608, but generally thought to appear in a reliable text for the first time in the Folio of I623, into Act 4. Two imprints of Q4 were printed in I608. One makes no mention on the title-page of the new material, and identifies the acting company anachronistically as the Lord Chamberlain's Men, a title abandoned when they became the King's Men shortly after James's accession. The other presents 'The Tragedy of King Richard the Second: With new additions of the Parliament Scene, and the deposing of King Richard, As it hath been lately acted by the Kinges Maiesties servants, at the Globe. By William Shakes-peare'.

QI, therefore, has widely acknowledged claims to an authenticity derived from a holograph manuscript, and its text, as attested by the fact of the first three quartos, is exceptionally popular and successful in the late Elizabethan market. Nevertheless, the structure of that text is consistently overlooked by editors in favour of Q4's 'new additions', a phrase in early modern play publication which has usually led editors to favour the earlier text instead (as in the case of, for example, The Spanish Tragedy, advertised with new additions in editions from $\mathrm{I} 602$ onwards but almost always edited now from the undated text of $c .1592$; and, further, seen in the editorial preference until recently for the I604 text of Dr Faustus rather than those later texts also advertising 'new additions'). Editors have treated what Q4 claims as 'additions' instead as 'omissions' from QqI-3 and, although they have tended to take QI as copy-text, they have always also included the Q4-only lines. Even Charlton Hinman in the context of reproducing Q I for a facsimile series dedicated to the integrity of early editions does not see Q I as a complete text, and, uniquely for that series, includes an appendix of the facsimile pages from $\mathrm{Q}_{4}$ for the additional passages. The ideological effects of the thoroughgoing editorial preference of the I608 text over the earlier texts in regard to the conduct of the play's Act 4 tend to be obscured by discussions about whether QqI-3 were censored; or, to put it another way, we have substituted an interest in the

3 The Works of William Shakespeare: 'The Cambridge Shakespeare', ed. William George Clark, William Aldis Wright and John Glover (Cambridge, I864), pp. 4, ix. On the scholarly and market significance of the Cambridge edition until the midtwentieth century, see Andrew Murphy, Shakespeare in Print (Cambridge, 2003), pp. 202-6.

4 John Dover Wilson, ed., King Richard II (Cambridge, I939). In the section on 'The copy for Richard II, I 597 and I623', Wilson asserts that QI 'has never, I think, been accepted without qualification as a basic text before the present edition' (p. I08).

5 Stanley Wells and Gary Taylor with John Jowett and William Montgomery, William Shakespeare: A Textual Companion (Oxford, I987), p. 306.

6 Charles R. Forker, ed., King Richard II, The Arden Shakespeare (London, 2002), p. 506.

7 Andrew Gurr, ed., King Richard II (Cambridge, I984), p. I75.

8 Charlton Hinman, ed., Richard the Second 1597: Shakespeare Quarto Facsimiles (Oxford, I966), p. xvi. A postscript dated a year later suggests that compositorial studies have suggested that perhaps 'the quarto provides an even less "generally satisfactory" text than we have heretofore thought': here the term 'generally satisfactory' seems to suggest something already actually rather unsatisfactory. 


\section{RICHARD II'S YORKIST EDITORS}

early modern production of these texts on stage and page for a reflective investigation of our contemporary editorial practice.

First, the matter of those contested lines, present for the first time in Q4. In the passage in Act 4, Richard is summoned by Bullingbrook, 'that in common view / He may surrender. So we shall proceed / Without suspicion' (4.I.I 55-7). ${ }^{9} \mathrm{No}$ location for this meeting is given in $\mathrm{Q}_{4}$ - the scene in QI, without Richard, is located in the stage direction: 'Enter Bullingbrooke with the Lords to parliament' (QI sig. G4). Richard enters, lecturing the noblemen for their fickle allegiance, offering the crown to Bullingbrook. Bullingbrook asks bluntly, 'Are you contented to resign the crown?', and Richard's contradictory answer, 'Aye - no. No aye' (200) encapsulates his fluctuation between resignation, self-pity, hauteur, and misery. Richard then lists the symbols of his office as if handing them over to Bullingbrook, and proclaims 'God save King Henry' (2 I9). Northumberland attempts to get Richard to read aloud a list of his crimes, but Richard accuses him of a betrayal for which 'water cannot wash away your sin' (24I). Richard continues to temporise, and calls for a looking glass, into which he gazes, asking 'Was this the face / That like the sun did make beholders wink?' (2823). The stage direction indicates that he smashes the glass, in this highly verbal play's most striking physical action, and he is sent from Bullingbrook's presence to the Tower.

There have been a number of bibliographic explanations for the divergence between QI and Q4, mostly arguing that the texts offer us 'a representative event in a narrative of control and subversion'. ${ }^{\text {Io }}$ The standard editorial position has been that the lines in Act 4 were cut because they were, in Andrew Gurr's words, 'politically sensitive'. For Gurr, 'it seems likely that some authority censored the deposition scene from the published text'; ${ }^{\text {II }}$ Charles Forker agrees that 'it seems probable that the "woeful pageant" of Richard's dethronement was considered too dangerous to print in I597'; 'I2 Wells and Taylor suggest that 'the actors themselves, the Bishop of London as licenser, or the printers and publishers may have cut the original version of the abdication scene from the papers which served as copy for QI', offering us a choice of agents but not of causes for the variation in the texts. ${ }^{13}$ This consensus is nuanced but not substantially altered by Annabel Patterson's view that the censorship may not be attributable to direct governmental intervention in the printed play but rather to a climate of 'public surveillance' by which 'the cultural forms of late Elizabethanism took the form they did because the queen and her ministers were watching', and by Cyndia Clegg's argument that, rather than the play's representation of usurpation or deposition being the problem, it is the particular prominence of Parliament which 'corroborated late-sixteenthcentury resistance theories'. ${ }^{14}$

The implicit argument that Q4 represents a more complete - 'original', in the terms of Wells and Taylor and Forker above - and thus textually preferable version of QI creates a standard modern text that is considered to be more politically radical than that of QI (since 'uncensored'). In fact the resulting text is more politically conservative than QI. Theories of censorship have often been implicitly predicated on an assumption that Richard's presence in Act 4, unique to Q4 and not part of the earlier texts, makes that text more challenging to monarchical authority in depicting the shocking overthrow of a lawful monarch. Here the tendency is for bibliographic and political interpretations to become mutually reinforcing, so that the near consensus that the lines present only in Q4 are in some sense radical is generated by the repeated speculation that they were previously censored, and the idea that they had to be censored

9 Quotations from the play, unless identified as QI, Q4 or F, are taken from Gurr's Cambridge edition.

Io Cyndia Clegg, "By the Choise and Inuitation of al the Realme": Richard II and Elizabethan Press Censorship', Shakespeare Quarterly, 48 (I997), 432-48; p. 432.

II Gurr, Richard II, pp. Iо, I75.

I2 Forker, Richard II, p. I65.

I3 Textual Companion, p. 307.

I4 Annabel Patterson, Shakespeare and the Popular Voice (Oxford, I989), p. 78; Clegg, “"By the Choise and Inuitation"”, p. 433. 


\section{EMMA SMITH}

gathers apparent corroboration from the interpretation of the scene as politically radical.

It is, however, at least possible that Richard's entry makes the scene not more transgressive but more orthodox, suggesting that only a king can 'unking' a king and that the act of usurpation should be figured as willed abdication rather than unwilled conquest. Q4 endorses Richard's kingly authority even at the moment when that authority is most under threat. The centrality the additional lines give to Richard is particularly noticeable in comparison to the scene in QqI-3, where York's rallying cry to crown 'Henry, of that name the fourth' (4.I.II2) does not require Richard's tacit, albeit reluctant, agreement, nor even his presence. When Richard is present in Act 4 in Q4, he may give up his crown and sceptre but he decisively seizes the stage and the audience, speaking I3 I lines in stark contrast to Bullingbrook's eleven. ${ }^{\mathrm{Is}}$ In QI Bullingbrook's 'We solemnly proclaime our Coronation' (QI: sig. H2) is decisive, following on from Northumberland's dispatch of the renegade Bishop of Carlisle to the Tower; the version in $\mathrm{Q}_{4}-$ 'we solemnely set downe / Our Coronation' (Q4: $\mathrm{H} 3 \mathrm{v}$ ), its metrics dissipated across the line break, is an anticlimactic response to Richard's own sardonic couplet as he exits the scene he has decisively dominated: 'O good convey, conveyors are you all, / That rise thus numbly by a true Kings fall'. It is the dethroned king Richard, not his rival Bullingbrook, who triumphs theatrically in this scene. ${ }^{16}$ This basic problem with the censorship theory was noted in I 890 by P. A. Daniel: 'it seems highly improbable that [the censor] should have contented himself with striking out a passage the only possible effect of which would be to excite the sympathy of the audience on behalf of the deposed monarch.' ${ }^{17}$ The corollary of this observation is that the editorial tradition that so consistently prefers Q4 over QI in the representation of Act 4 is similarly sympathetically disposed to its martyr Richard.

Without those additional lines, the play as printed in I597 and I 598 throws particular dramatic emphasis instead onto the scene in 3.3 , when Richard and Bullingbrook meet face to face at Flint
Castle. Richard's rhetoric in this scene stands in for the rhetoric of abdication in Act 4 in Q4, and employs a similar catalogue of renunciation:

I'll give my jewels for a set of beads, My gorgeous palace for a hermitage, My gay apparel for an almsman's gown, My figured goblets for a dish of wood, My sceptre for a palmer's walking staff, My subjects for a pair of carvèd saints, And my large kingdom for a little grave.

$(3 \cdot 3 \cdot 147-52)$

While Richard may attempt to assert a moral superiority through these religious substitutes, the one prop prominently missing from this list is the crown. Abdication is thus deferred, lexically and syntactically. The imagery of renouncing the costly symbols of office is repeated when Richard enters

Is Few commentators on the Q4 material have followed A.W. Pollard's contention that the lines were cut not primarily for political but for dramaturgical reasons, in his suggestion that the 'Lord Chamberlain's servants in I 597 may not impossibly have thought that there was a danger of "too much Richard" and cut the lines out in the acting version from which QI was printed' (A. W. Pollard, intr., King Richard II: A New Quarto [London, I9I6], p. 63). The Complete Works [the RSC Shakespeare], ed. Jonathan Bate and Eric Rasmussen (London, 2007), offers valuable statistical information on the distribution of lines/number of speeches/scenes on stage. Their Folio text gives Richard 27\%/98/9 and Bullingbrook I $5 \% / 90 / 8$ (p. 83 I): a similar calculation for QI would rebalance by taking I 3 I lines from Richard (around 6\% of the total), I 6 speeches and one scene. The reduction in the numbers for Bullingbrook would be i I lines and I I speeches.

I6 The evidence of the early chronicles, diverging on partisan lines, also bears this out: it is in pro-Ricardian accounts that the suggestion that the king himself be called to Parliament is found, although his resignation is usually described as taking place in the Tower of London, with the document of abdication later read out in Parliament in his absence. Jean Froissart's late fourteenth-century account, sympathetic to Richard, has Richard passing the sceptre and crown to Bullingbrook as in Q4 4.I; anti-Ricardian chroniclers do not include such a meeting. See Louisa D. Duls, Richard II in the Early Chronicles (The Hague and Paris, I975), pp. I I 254 and Geoffrey Bullough, Narrative and Dramatic Sources of Shakespeare III (London, I966), pp. 430-I.

17 Daniel is quoted in A New Variorum Edition of Shakespeare: The Life and Death of King Richard The Second, ed. Matthew W. Black (Philadelphia, I955), p. 373. 


\section{RICHARD II'S YORKIST EDITORS}

in 4.I in $\mathrm{Q}_{4}$, or pre-empted when he doesn't in QI. In 3.3 Richard descends from the walls to meet Bullingbrook, and finally to receive the appropriate tribute of subject to sovereign: 'he kneeles downe' (QI: sig. G2), but the end of the scene seems to register Richard's capitulation: 'what you will have I'll give, and willing too, / For do we must what force will have us do. / Set on towards London, cousin, is it so?' (3.3.204-6). Richard recognizes that he must submit, like a subject, to 'what force will have us do', and he addresses Bullingbrook here with the horizontal term of kinship, 'cousin'. The transition at this point in the play is not a formal one marked by the physical props of office as in Act 4, but rather a political conversion signalled linguistically - as has been characteristic of a play beginning with a deferred duel and continuing to structure itself around the anticlimaxes of postponed or occluded single combat. The scene, at the structural midpoint of the play, anatomizes the definitive shift of power from Richard towards Bullingbrook: in QI it is the last time they are on stage together. Although all the quarto texts carry the generic designation of 'tragedy' on their titlepages, QI seems particularly to emphasize the historical transition from one sovereign to the next in placing the tipping point in the centre of the play. Q4, and the editorial tradition that so decisively favours that text, prefer an emphasis on Richard's own tragic fall by bringing him back on stage in Act 4 for a further encounter with his political nemesis. Like Richard himself, that is to say, the editorial preference for $\mathrm{Q}_{4}$ seems unwilling to submit to the rise of Bullingbrook without one last rhetorical encounter.

That the additional lines in Q4 may actually enforce Richard's sovereign authority rather than, as has been assumed, that they are the apogee of the play's dangerous politics, is further suggested, if not explicitly owned, by the editorial language used to describe them. The title of Q4 published by William Whyte in I608 which alludes to the textual difference from previous editions describes that new material as the 'parliament scene' - it is, as critics have identified, thus labelled a scene of parliamentary authority in which, effectively, a constitutionally sanctioned part of the state enacts a particular legal judgement on a monarch. ${ }^{18}$ Editors have, however, tended to prefer a different designation, referring to the extended 4.I as a 'deposition scene' - a term which cannot be readily traced to the early modern context since it is a description that appears in neither the play nor its known sources. Malone uses the word 'deposition' twice in his account of the play's textual history, but none of the eighteenth-century editors, either Rowe, Pope, Theobald, Johnson or Malone, uses the term 'deposition scene'. ${ }^{\mathrm{I} 9}$ By the time of $\mathrm{A}$. W. Pollard's facsimile of $\mathrm{Q}_{3}$ in I9I6, the 'so-called Deposition Scene' is identified, and this terminology is corroborated through New Bibliographic work during the early twentieth century, including E. K. Chambers's William Shakespeare: Facts and Problems of I930. ${ }^{20}$ John Dover Wilson's I939 edition, where the suggestion that 'Shakespeare may have fallen in love with, and lingered over, Act 4' sounds strangely like a projection of editorial rather than authorial fascination, discusses 'the so-called "Deposition" scene' and continues to place the word in quotation marks, without ever identifying what is being quoted. ${ }^{2 I}$ The term is used without question or explanation but sometimes preceded by the shrug 'so-called' by the editors of Arden 2 and 3, by Andrew Gurr for the New Cambridge edition, by Herschel Baker in The Riverside Shakespeare, Jonathan Bate in The RSC Shakespeare and Katharine Eisaman Maus in the Norton Shakespeare. It seems that 'deposition scene' is a term which solidifies under the auspices of New Bibliography, and one which, like other of that movement's terms including 'bad quarto' and 'foul papers', has a moralistic edge beneath its aspirations to descriptive neutrality.

\footnotetext{
I8 Clegg "'By the Choise and Inuitation", p. 433.

I9 Edmund Malone, The plays and poems of William Shakspeare, in ten volumes (London, I790), vol. I, p. 3 I 5.

20 Pollard, Richard II, p. 32; E. K. Chambers, William Shakespeare: A Study of Facts and Problems (Oxford, I930), vol. I, p. 355 .

2I Wilson, Richard II, pp. xiv, 207.
} 


\section{EMMA SMITH}

The noun 'deposition' as a noun does not appear in the play nor anywhere in the Shakespeare canon. The verb 'depose' is used ten times in Richard II. Three occurrences do not directly connote Richard's dethronement but may be proleptic references to it (I.3.30; 2.I.I07-8). Two are used in the conversation between the Gardener and the others in 3.4, for which the Queen rebukes them in strongly religious terms: 'What Eve, what serpent hath suggested thee / To make a second fall of cursèd man? / Why dost thou say King Richard is deposed?' (3.4.75-7). The other four are all used by Richard to describe what has been done to him. Initially he defiantly resists Bullingbrook's ambitions, in a speech excerpted by Robert Allott for the section 'Kings' in his I600 anthology Englands Parnassus ('The breath of worldly men cannot depose / The deputy elected by the Lord', 3.2.567). ${ }^{22}$ Then, in lines unique to $\mathrm{Q}_{4}$, Richard quibbles on the impossibility of taking 'griefs' along with the crown: 'You may my glories and my state depose, / But not my griefs' (4.I.I9I-2), and warns the noblemen pressing him to read out the accusations against him that they might read in the book of their own sins 'one heinous Article / Containing the deposing of a king' (4.I.232-3). Finally, the same phrase with a significant adjective creeps into his farewell to his queen, predicting mourning 'For the deposing of a rightful king' (5.I.5O, emphasis added).

This last connection of the verb 'to depose' with the implication of 'a rightful king' is embedded throughout Richard's usage of the word. It is more associated with his vocabulary than with any other character, and thus 'deposing', we might say, registers the action of the play as seen from Richard's perspective. It figures the play's action as something happening to him, rather than something happening to, or being done by, Bullingbrook. Walter Pater's remark that 'Richard "deposes" himself' in the course of his appearance in 4.I captures this paradox of self-assertion. ${ }^{23}$ In its connotations for 'depose' the play follows the usage in Holinshed's Chronicles, one of its major sources, where sympathetic counsellors suggest that Richard 'willinglie... suffer himselfe to be deposed, and to resigne his right of his own accord'. ${ }^{24}$ This repeated association with Richard himself in the play and its immediate sources makes evident that 'depose' and 'deposition' are not neutral terms available for bibliographic adoption. Rather, they are already significantly ideologically committed, and committed to Richard's own cause.

To emphasize this implicit bias we can see that other meanings of the noun 'deposition' are immanent in its widespread bibliographic use as a term for the contested material in Richard II. The OED's first meaning, dating from the early sixteenth century onwards, is 'the taking down of the body of Christ from the cross; a representation of this in art' (OED deposition I). In echoing this sense of the word the editorial tradition is complicit in Richard's own Christology which figures his opponents as Judases (4.I.I70) and Pilates (4.I.2389) bringing him to a 'sour cross' (4.I.240). The OED's second meaning, 'The action of laying down, laying aside, or putting away (e.g. a burden)' (OED deposition 2) is also implicitly sympathetic to Richard's own rhetoric of grief and burden: 'down and full of tears am I'; 'your cares set up do not pluck my cares down'; 'I give this heavy weight from off my head' (4.I.I 87, I94, 203). In imposing the term 'deposition' on the textually contested material, and in choosing always to reprint that material, the editing of Richard II tacitly sides with Richard's perspective on events and with Richard's own topos of martyrdom.

Part of the theatrical attraction of the $\mathrm{Q}_{4}$ passage is that in visualizing the transfer of sovereignty as a transfer of kingly props, the scene promises a distilled ritual tableau of its theme of shifting authority. It seems to be the moment when kingship is reassigned. But when Richard enters in Q4, he is already acknowledging Bullingbrook as king: 'Alack, why am I sent for to a king / Before I have shook off the regal thoughts / Wherewith I reigned?' (4.I.I62-4). This apparent admission - although the pointed use of the indefinite

\footnotetext{
22 Robert Allott, Englands Parnassus (London, I600), p. I 56.

23 Walter Pater, Appreciations (London, I9Io), p. 198.

24 Bullough, Narrative and Dramatic Sources, p. 406.
} 


\section{RICHARD II'S YORKIST EDITORS}

article 'a king' undermines Richard's ostensible deference - obscures a question rarely directly addressed in criticism of this play: when does Richard actually cease to be king and Bullingbrook begin to be king? Are these necessarily at the same moment? The shifting power balance between two rivals who never actually fight for the throne is registered throughout the play in linguistic nuance, by acknowledging, or withholding acknowledgement of, the status of the other. Does power change hands when Bullingbrook condemns Bushy and Green to execution and repeals his own banishment in 3.I? Or is it when Richard admits himself 'subjected' (3.2.176), and Bullingbrook quibbles that the castle 'contains no king' (3.3.23), or when Richard ironically names 'King Bullingbrook' (3.3.I73), or when York proclaims Bullingbrook 'Henry, of that name the fourth' to which Bullingbrook replies 'In God's name I'll ascend the regal throne' (4.I.I I $2-3$ ), or when Richard notes 'God save the king, although I be not he' (4.I.I74), or when he is taken to the Tower, or when Bullingbrook arranges his own coronation, or when off-stage and reported by York - the people of London greet Bullingbrook with acclaim and snub Richard, when in 5.3 Bullingbrook enters as crowned king, or when Richard is murdered in 5.5 ? The cumulative suggestion is that it is all of these - or rather that the process by which the play dethrones one king and crowns another is just that, a process, rather than an event. Rather than dramatizing the ineffable moment by which a subject becomes a king and a king becomes a subject, the play inscribes a serial effect by which Richard's moral and material hold on the throne is weakened and Bullingbrook's grows stronger.

This shift is registered by, and conveyed in, serial verbal processes. When Richard haughtily enquires at Flint Castle 'how dare thy joints forget / To pay their awful duty to our presence?' (3.3.75-6), his words are an implicit stage direction: Northumberland has remained standing in front of his king. Such meaningful physical gestures of resistance or obeisance on the stage have their parallel in the apparatus of the play on the page. The apparatus of different texts of Richard II participates in, and mystifies, the questions of the ontology of kingship enacted by the events of the play: the play, and its texts, recognize that naming is the corollary of and demonstration of sovereign authority. The early texts deploy their ability to name or proclaim a king in ways that are materially, and ideologically, distinct. What modern editors have done, as will be shown, is to ignore these nuances. As Random Cloud has noted, the supposition that the unspoken text of the printed play as reported by its speech prefixes and stage directions is 'centrifugal from the aesthetic vision of a play', or 'mere epiphenomena of the play, scaffolding to be dismantled when it could stand on its own' is problematic. ${ }^{25}$ In Richard II we see a remarkably interconnected narrative of spoken and unspoken text which is obscured when editors take down that paratextual scaffolding.

To trace this narrative, I want to take QI's naming of Richard and Bullingbrook. ${ }^{26}$ The opening of QI gives us a typographical version of a flourish: 'Enter King Richard, John of Gaunt, with other Nobles and attendants'. The first speech prefix, centred like a heading or stage direction rather than the usually left-aligned type, is 'King Richard'. Subsequent speech prefixes on this page are 'King', and this designation continues in prefixes and stage directions through the next three acts, with

25 Random Cloud, 'The Psychopathology of Everyday Art', The Elizabethan Theatre IX, ed. G. R. Hibbard (Ontario, I98I), pp. I00-68; p. I02. Parts of Cloud's essay - which has a much broader compass than Richard II - overlap with my concerns here, in some of his comments on naming in QI and on equivocation around the naming of Richard and Bullingbrook. Cloud's analysis is characteristically provocative and playful rather than exhaustive: I have extended his analysis to look more sustainedly at the editorial tradition and at the implications of our discussions of and preference for Q4, which he does not address. My argument suggests a more ideologically purposive collocation of editorial decisions rather than Cloud's suggestive anatomy of textual equivocation.

26 Forker's Appendix I (pp. 506-4I) analyses compositorial studies of QI: the agreed allocation of copy between Hinman's Compositor A and Compositor S does not parallel the speech prefixes analysed in this essay (so it is not possible to demonstrate that one compositor prefers to call Richard king and the other does not, for example). 


\section{EMMA SMITH}

Bullingbrook usually called 'Duke of Hereford' in stage directions and 'Bull.' or 'Bulling' in speech prefixes. The Flint Castle scene (3.3) in the middle of the play might be thought to be its political fulcrum: the first encounter between the illegally returned exile and his king is the moment at which Richard's kingship first comes under most direct nominal pressure, a pressure echoed and verbalized in Bullingbrook's contemptuous repetition of the phrase 'King Richard' $(3 \cdot 3 \cdot 36,47,54,61)$. It is here that Bullingbrook's own attack on Richard's kingly authority begins to interweave with the play's paratextual apparatus: having heard the mocking echo of that phrase 'King Richard' we get the play's first stage direction to strip Richard of his royal prefix: 'The trumpets sound, Richard appeareth on the walls' (F4v). The royal trumpets may still be flourishing as the king steps onto the battlements, and as York says, 'yet looks he like a king' (3.3.68; perhaps like here could signify mere resemblance to, rather than identity with, kingship), but the stage direction no longer calls him king. This is a potentially significant textual moment in registering the diminution of Richard's authority, a movement which is amplified in subsequent scenes.

In QI, Bullingbrook ends 4.I with the preparations for his coronation. When in $\mathrm{Q}_{4}$ Richard is brought in he enters as 'king Richard', but his speech prefix is, for the first time in the play, 'Rich.' (Q4: sig. HIV). This naming manages to suggest a tailing off of his claim to the apparently absolute title of 'King'. This curious effect may echo one of Richard's own most striking conceits:

Now is this golden crown like a deep well That owes two buckets, filling one another, The emptier ever dancing in the air,

The other down, unseen and full of water.

That bucket, down and full of tears, am I,

Drinking my griefs whilst you mount up on high.

(4.I.I $83-8)$

Richard's conceit here suggests that kingship, a well with two buckets, is both a binary - one bucket or antagonist, is high in the air while the other is down in the depths - and a continuum - the movement depends on the interconnectedness of the two buckets and their mutually dependent vertical traverse. The image serves to metonymize the play's own complicated inscription of the quality of kingship: Richard II simultaneously upholds kingship as an absolute qualitative difference between persons in a hierarchy which has only two categories: king, and not-king, but also suggests it is a relative condition, in which the king/not-king binary may be complicated by a continuum of stages in between. One of these stages is indicated by, or even inheres in, the speech prefix 'Rich.' rather than the previously held 'King'. In QI the first appearance of the speech prefix 'Rich.' is at his next appearance in which he bids the queen farewell, but here the speech prefixes waver: the new diminutive 'Rich.' is attached to a speech of considerable marital tenderness - 'Learn, good soul, / To think our former state a happy dream' (5.I.I7-I8) - but the rest of his speeches in this scene are attached to 'King'. The Yorks discuss the shift in popularity between Richard and Bullingbrook, but by the next time Bullingbrook enters the play the stage direction is uncompromising: 'Enter the King with his nobles' (QI: sig. IV). Somewhere, off-stage, the play has registered a political change. The word 'King' is now attached to Bullingbrook.

The speech prefix following this stage direction is less assured. Bullingbrook's first speech prefix as king in this play carries the speech prefix 'King H.' (QI: sig. Iv). In this qualifying initial, the paratextual apparatus of the quarto text registers something crucial. What has happened in this Richard II is not just a political reshuffle, not merely the substitution of one scion of the Black Prince for another. Rather, something has happened to relativize a former absolute. 'King' now has an initial to qualify it: it is provisional, circumstantial. 'King $H$.' is a formulation which connotes, embodies, and remembers its implicit shadow 'King R.' even at the moment when it seeks to consign him to history. It is not Bullingbrook's individual claim to the throne that is placed under suspicion by the formulation, but rather the sustaining myth of autonomous kingship. Or, to use the terms of Ernst Kantorowicz's The King's Two Bodies, an influential theory which derives from, as well as illuminates, 


\section{RICHARD II'S YORKIST EDITORS}

Richard II: in 'King H.' the troubling fact of the body natural refuses to accede to the fiction of the

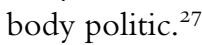

The significance of this designation can be seen by comparing it to other playtexts. This label of 'King' plus initial does not appear anywhere else in the early texts of Shakespeare's plays where new or contesting kings appear in the printed text. In Henry $V$, for example, Qі (I600) and the Folio text each designates both the King of France and Henry as 'King' in speech prefixes and stage directions. In the last scene of Henry $V$, where the two kings meet, there is a shift in the speech prefixes. The Folio opts for 'France' and 'England', reverting to 'King' for Henry's speech prefixes in dialogue with Katherine when the French king has exited. In Q I the French king is prefixed 'Fran.' and the new and familiar 'Harry' is introduced for Henry, a speech prefix he retains for the remainder of the play. Even where there are two kings simultaneously of different realms each called 'King' in earlier speech prefixes the denominator 'king' does not take on a modifier. QI of 3 Henry VI, The True Tragedy of Richard Duke of York (I595) uses forenames as speech prefixes for the male protagonists throughout its story of the changing fortunes of Henry VI, Edward IV and the Richard Duke of Gloucester. In QI of Richard III (I 597), Richard is originally called 'Glo.' and the speech prefix 'Kin.' is given to Edward. When Richard takes over the throne the textual acknowledgement is immediate: at 4.2 the stage direction is 'Enter Richard crownd' (sig. H4v) and the speech prefixes follow as 'King'. The political impact of the paratexual references in the Folio text of Richard III is rather different: here Richard is called 'Rich' or 'Richard' throughout, and the equivalent stage direction when he enters crowned observes more sceptically, 'Enter Richard in pompe' (I94). He is only elevated with an honorific speech prefix in a (failed) paratextual attempt to avoid confusion when, in the Folio's final battle, 'Rich.' meets his nemesis and paratextual near-doppelgänger 'Richm.'. Similarly, the Folio Macbeth calls Duncan 'King' in speech prefixes and stage directions, but never acknowledges Macbeth's violent and illegitimate rule. At 3.I we have 'Enter Macbeth as king'
(I39), but 'Macb.' is stoutly retained as the speech prefix throughout. Thus, while there are precedents and parallels for the paratextual management of two kings or a transfer of sovereignty within a play, none of these uses the semantics of qualified sovereignty 'King H.' seen in Q I Richard II.

'King $H$.' is the speech prefix formulation for Bullingbrook's first entrance as Henry IV in all the quartos. The majority of speech prefixes in 5.3 are 'King', but there are a couple of further appearances of the more nervous 'King H.'. The point here is not about a preference for QI or Q4, but, as I go on to show, about what editors choose to do with these paratexual signals in Richard II. And if a new king has been proclaimed, the old one must, logically, have been demoted. The quartos have Richard's soliloquy in Act 5 introduced with the stage direction 'Enter Richard alone' (QI: sig. I3v ${ }^{\circ}$; Q4: sig. K) and adopt that prefix 'Rich' for the rest of his scene, and thus it is 'Richard', not 'King Richard', whom Exton kills, even as he calls him 'this dead king' (5.5.II7). But the quartos all do something interesting after this. In the stage direction immediately following Exton's exit with the body of Richard - the moment when it might be anticipated that the death of the previous king actually corroborates and legitimates, albeit belatedly, Bullingbrook's own kingship - the text withdraws its ostensible support. His next entrance in 5.6 is 'Enter Bullingbrooke with the Duke of Yorke' (QI: sig. K; Q4: sig. K3), although the speech prefixes reassert 'King' throughout this final scene.

A brief comparison with the Folio text clarifies what is at stake, ideologically, in the quartos' naming. F uses 'Rich.' as speech prefix throughout, and

27 Ernst H. Kantorowicz, The King's Two Bodies: A Study in Medieval Political Theology (Princeton, NJ, 1957): Kantorowicz's influential account of Shakespeare's Richard II as 'the tragedy of the King's Two Bodies' (p. 26) is at pp. 244I. David Norbrook discusses Kantorowicz's study in 'The Emperor's New Body? Richard II, Ernst Kantorowicz, and the Politics of Shakespeare Criticism', Textual Practice, Io (I996), 329-57. Margaret Shewring gives an account of John Barton's innovative I973 RSC production and its use of the 'two bodies' concept in her Shakespeare in Performance: King Richard II (Manchester, I996). 


\section{EMMA SMITH}

tends in the first half of the play to call Richard 'King' in stage directions. It never calls Bullingbrook king. Aumerle's question at 5.3 .23 , 'Where is the King?' is thus moot, for in the Folio text the stage direction entrance does not name one: 'Enter Bullingbrooke, Percie, and other Lords' (43). In this it iterates Richard's own refusal to acknowledge his successor, naming him 'Bullingbrook' twice in his soliloquy in $5.4(37,59)$. There are many implications in this difference. F Richard II more closely anticipates moralized critical arguments about the dethroning of Richard as the tragic catalyst for a cycle of history plays in which rightful authority is ultimately restored in the union of York and Lancaster and the accession of Henry VII at the end of Richard III, what E. M. W. Tillyard influentially described as an 'epic of England', 'beginning in prosperity, the distortion of prosperity by a crime, civil war, and ultimate renewal of prosperity'. ${ }^{28}$ By not calling Bullingbrook 'King' the Folio text suggests that his rule is illegitimate and focuses tragic attention on Richard's demise. By contrast the quartos accede to the inevitable transfer of power crucial to the succession dynamic of the history play, naming a new king without demur. (The differences between Q and F Richard III, discussed above, share this politics, with $Q$ ratifying Richard's coronation and $\mathrm{F}$ largely withholding that support.) Ultimately, the most significant aspect of the quarto texts is not that they acknowledge Bullingbrook as sovereign but that their version of compromised kingship in the prefix 'King H.' registers an assault on the mystified ontology of monarchy. The difference between F and Qq, that is to say, is not that one endorses Richard and the other Bullingbrook but rather that $\mathrm{F}$ corroborates an essentialist notion of kingship and QI compromises that fiction.

Discussing the importance of consolidating nominal character identities which early playtexts represent under different headings in his Re-editing Shakespeare for the Modern Reader, Stanley Wells suggests that it is "proper...to call Bolingbroke "King Henry" after his accession, a change normally made by editors (following the First Quarto, in which however it occurs at a later point in the action than in edited texts)'. ${ }^{29}$ Wells does not make clear whether the notion of propriety from which he draws authority is an editorial matter or one of royal etiquette, but the sequential confusion of his parenthesis - following, however, later - is telling. Where do editors place the change from surname to royal forename? At what point does the editor, too, declare himself, willingly or pragmatically, a Lancastrian, or kneel down in textual obeisance before a new sovereign? The ways in which editors handle the transition of power between Richard and Bullingbrook shapes the kind of political sympathies they allow the play, and, as I will outline, the majority of the editorial tradition endorses Richard as king throughout his play and does not acknowledge Bullingbrook's coronation.

No edition until the twentieth century registers, following the quartos, the change in denominating Richard and Bullingbrook. Significantly, the first to do so is that of Dover Wilson, published in I939 and prepared under the pressure of the abdication crisis of 1936, in which Edward VIII abdicated in favour of his brother. Wilson uses the speech prefixes ' $K$. Richard' and 'Bolingbroke' for the first three acts. ${ }^{30}$ In Act 4 Richard speaks in the Parliament scene as ' $K$. Richard': the stage direction has, in a faint version of the novelistic stage direction interpolation for which Dover Wilson's editions have been so roundly criticized: 'York returns with King Richard, guarded and stripped of his royal robes' but not, clearly, of his royal title. ${ }^{3 \mathrm{I}}$ Two hundred lines later, however, he is led off: '[certain lords conduct Richard guarded from the hall]', and from then onwards, Richard's changed

28 E. M. W. Tillyard, Shakespeare's History Plays (London, I944), 3I3, pp. 26I.

29 Stanley Wells, Re-Editing Shakespeare for the Modern Reader (Oxford, I984), p. 65.

30 The history of how the standard form in Qq and F-Bullingbrook - became the long-standard 'Bolingbroke' could be the subject of another parallel investigation into the politics of editing Richard II - in that case starting with Alexander Pope's edition of 1725 which introduced the now common spelling, in homage to his political and intellectual friendship with the first Viscount Bolingbroke, then in exile for his Jacobite sympathies. In this article I call the character 'Bullingbrook' except in quotations.

3I Wilson, Richard II, p. 73. 


\section{RICHARD II'S YORKIST EDITORS}

status is marked by the dropping of 'King' from stage direction and speech prefix..$^{32}$ Interestingly, however, there is no corresponding change in the denotation of Bolingbroke, who continues to be referred to in speech prefixes as 'Bolingbroke' for the remainder of the play. Dover Wilson's Richard II strips one king of sovereignty but does not quite like to crown another in his place. Richard's decline is registered, but the attendant rise of Bullingbrook is unremarked.

Peter Ure's policy for the Arden 2 edition (1956) is 'based on QI', ${ }^{33}$ but registers no change at all in the way the textual apparatus refers to the central protagonists. Ure retains throughout the speech prefixes 'Rich.' and 'Bol.'. His opening stage direction in 5.3 , the point at which the quartos recognize Bullingbrook as king, also has no truck with his ambition, following the Folio to remark severely 'Enter Bolingbroke, Percy, and other Lords'. ${ }^{34}$ This edition resolutely does not cooperate with the transfer of power that the play enacts. Throughout his New Cambridge Shakespeare edition (I984, revised edn 2003), Andrew Gurr also keeps constant speech prefixes: 'Richard' and 'Bullingbrook', even while arguing that 'the $Q$ headings reflect the author's sense of the changes produced by the events of the play while F's consistency reflects the needs of the playhouse'. ${ }^{35}$ Gurr's recognition that Bullingbrook has assumed the crown is grudging. He suspends, or even ironizes, Bullingbrook's aspiration in parentheses - 'Enter Bullingbrook [as king], Percy and other Lords' - rather than QI's 'Enter the King with his nobles' at the beginning of 5.3. This designation is interesting, not least since square brackets within stage directions are conventionally used for editorial additions, rather than to make suspect those stage directions which are part of the earliest texts. No explanation for this emendation is offered by Gurr's own statement of policy on stage directions: 'In general for this edition the more elaborate stage direction, whether from $\mathrm{Q}$ or $\mathrm{F}$, is given in the text, though where the variations are unimportant $\mathrm{Q}$ has been preferred. ${ }^{36}$

The Folger text, edited by Barbara Mowat and Paul Werstine (1996), takes up the issue with declarative simplicity. 'King Richard' and 'Boling- broke' are employed as speech prefixes until 5.3, when 'King Henry' and 'Richard' are adopted. The logic here suggests that the same (off-stage) moment transforms 'King Richard' into 'Richard' and 'Bolingbroke' into 'King Henry'. In the New Penguin edition (I969), Stanley Wells opts for a different strategy, calling Richard 'King Richard' to the end of Act 3, then 'Richard' from 4.I onwards. 'Bolingbroke' is used until 5.3, when he enters 'now King Henry', and this shift is recorded in the speech prefixes of the rest of the play. Richard steps down, nominally, that is to say, some time before Bullingbrook steps up; this does not dramatize a moment, but rather a period, of regal changeover, and Act 4 and the early scenes of Act 5 seem to take place in a textual interregnum. ${ }^{37}$ The same solution is adopted by Wells and Taylor's complete Oxford edition (I986), and in the Norton text which follows it: Richard is named as 'King Richard' in speech prefixes and stage directions until Act 4 . On his entry into the Parliament scene the text calls him 'Richard', but continues to name 'Bolingbroke'. Some nifty editorial stage directions in $4 . \mathrm{I}$ focus in and clarify the moment of the transfer of power. Bullingbrook's question 'Are you contented to resign the crown?' (4.I.I90) elicits Richard's contorted reply 'Ay, no; no, ay' and a long, rhetorical speech which is at once self-abnegating and aggrandizing. Richard's 'I give this heavy weight from off my head, / And this unwieldy sceptre from my hand' is fixed as indicative of action (rather than, as might be thought characteristic, substitutive for it) by Oxford's interpolated stage directions 'Bolingbroke accepts the crown' and 'Bolingbroke accepts the sceptre' (4.I.I9I-5). Strikingly these added stage directions construct as the grammatical agent of this speech of decoronation - the subject - not Richard but Bullingbrook, intervening in the text

32 Wilson, Richard II, p. 78

33 Peter Ure, ed., King Richard II (London, I956), p. xxvii.

34 Ure, Richard II, p. I 59.

35 Gurr, Richard II, p. I 88.

${ }^{36}$ Gurr, Richard II, p. I77.

37 Stanley Wells, ed., Richard II, New Penguin Shakespeare (Harmondsworth, I969). 


\section{EMMA SMITH}

to give Bullingbrook a more active role. ${ }^{38}$ In $5 \cdot 3$ Bullingbrook enters 'crowned King Henry' in the stage direction, and his speech prefixes endorse this newly royal identity, denoting him 'King Henry'. Richard's soliloquy in Act 5 is given by 'Richard', and it is 'Richard's body' that Exton carts off-stage at the end of 5.5 .

All of these versions, except Ure's, work to manage both promotion and attendant demotion. The Riverside edition (I974), by contrast, uses consistent 'K. Rich.' and 'Bull.' speech prefixes until 5.3, when the stage direction's deployment of both QI's definite article and the reminder that this king is not Richard creates a syntactically uneasy amalgam: 'Enter the King [Henry] with his nobles'. ${ }^{39}$ Henry retains this title for the rest of the play in the speech prefix ' $K$. Hen', although Richard, too, continues to be called ' $K$. Rich.' up to his death. Both, that is to say, are kings simultaneously: Bullingbrook's accession does not have to mean that Richard has necessarily forfeited the crown. The king in this edition really does have two bodies. This doubling of kings is the route followed by Charles Forker's Arden 3 edition (2002), which is the only edition to discuss in detail the difficulties of this naming issue. ${ }^{40}$ The Arden names Richard 'King Richard' in the speech prefixes throughout the play, pitting him against 'Bolingbroke' for the first four acts. Forker's policy of recording Folio stage directions results in a palimpsest of names for his stage direction at 5.3: 'Enter ${ }^{\mathrm{F}}$ Bolingbroke, ${ }^{\mathrm{F}}$ [as] KING [HenRY,] with [Harry $^{\mathrm{F}}$ Percy and other Lords ${ }^{\mathrm{F}}$, Bullingbrook is thence given the speech prefix 'King Henry'. ${ }^{4}$ Scenes 5.3, 5.5. and 5.6 thus alternate between two kings and two courts: the logic of the speech prefixes is that Richard and Henry are both king at the same time.

The editors here deal with the early texts' dilated transfers of power between Richard and Bullingbrook in different ways, but almost none of these editions seems to subscribe to the dramatic, constitutional or material possibility that Richard has ceased to be king and Bullingbrook has become king in his place. None can quite ratify the strangeness of the process Richard calls 'unking[ing]', or its unspoken corollary, 'kinging'. Only Wells and Wells-Taylor enact without apparent fuss that proper, Polonius-like switch from old king to new, evincing no political discomfort with the structure of deposition and coronation the play depicts. Even these two editions, however, introduce a period of effective interregnum in which neither Richard nor Bullingbrook is king. No editor preserves the speech prefix that is most significant in revealing the ontological and political disturbance of the play's events: 'King H.'. Thus we now read Richard II in texts evincing a sustained ideological discomfort with the transfer of power the play dramatizes, even while their editorial apparatus tends to reiterate the claims for the play's political topicality and its probable performance in Essex's rebellion. The unexamined preference for Q4 and its dramatic sympathy for Richard reveals an editorial bias towards the incumbent king rather than his challenger, and the general unwillingness both to demote Richard from the office of king and to promote Bullingbrook seems to indicate that the historical fact of the change of sovereign is paradoxically more difficult for twentieth-century readers than it was for late sixteenth-century ones. The current critical preoccupation with the possible censorship of the Elizabethan quartos and their significance to early modern monarchical politics seems curiously to have distracted modern scholars and editors from investigating their ongoing power to disturb political and editorial hierarchies: the result is that it is more difficult now than it was four hundred years ago for readers of Shakespeare's Richard II to avoid Richard's own martyrology and to acknowledge Henry Bullingbrook as Henry IV.

\footnotetext{
${ }^{8}$ Stanley Wells and Gary Taylor, William Shakespeare: The Complete Works (Oxford, I985), p. 388.

39 G. Blakemore Evans and J. J. M. Tobin (eds.), The Riverside Shakespeare: Second Edition (Boston and New York, 1997), p. 875 .

40 Forker, Richard II, pp. 5IO-I2.

4I Forker, Richard II, p. $44^{2}$.
} 